This item was submitted to Loughborough's Research Repository by the author.

Items in Figshare are protected by copyright, with all rights reserved, unless otherwise indicated.

\title{
Response of Sphagnum papillosum and Drosera rotundifolia to reduced and oxidized wet nitrogen deposition
}

PLEASE CITE THE PUBLISHED VERSION

http://dx.doi.org/10.1007/s12224-011-9114-9

\section{PUBLISHER}

Springer Netherlands (@ Institute of Botany, Academy of Sciences of the Czech Republic)

\section{VERSION}

AM (Accepted Manuscript)

\section{LICENCE}

CC BY-NC-ND 4.0

\section{REPOSITORY RECORD}

Millett, Jonathan, lan D. Leith, Lucy J. Sheppard, and Jason Newton. 2019. "Response of Sphagnum Papillosum and Drosera Rotundifolia to Reduced and Oxidized Wet Nitrogen Deposition". figshare. https://hdl.handle.net/2134/13431. 
This item was submitted to Loughborough's Institutional Repository (https://dspace.lboro.ac.uk/) by the author and is made available under the following Creative Commons Licence conditions.

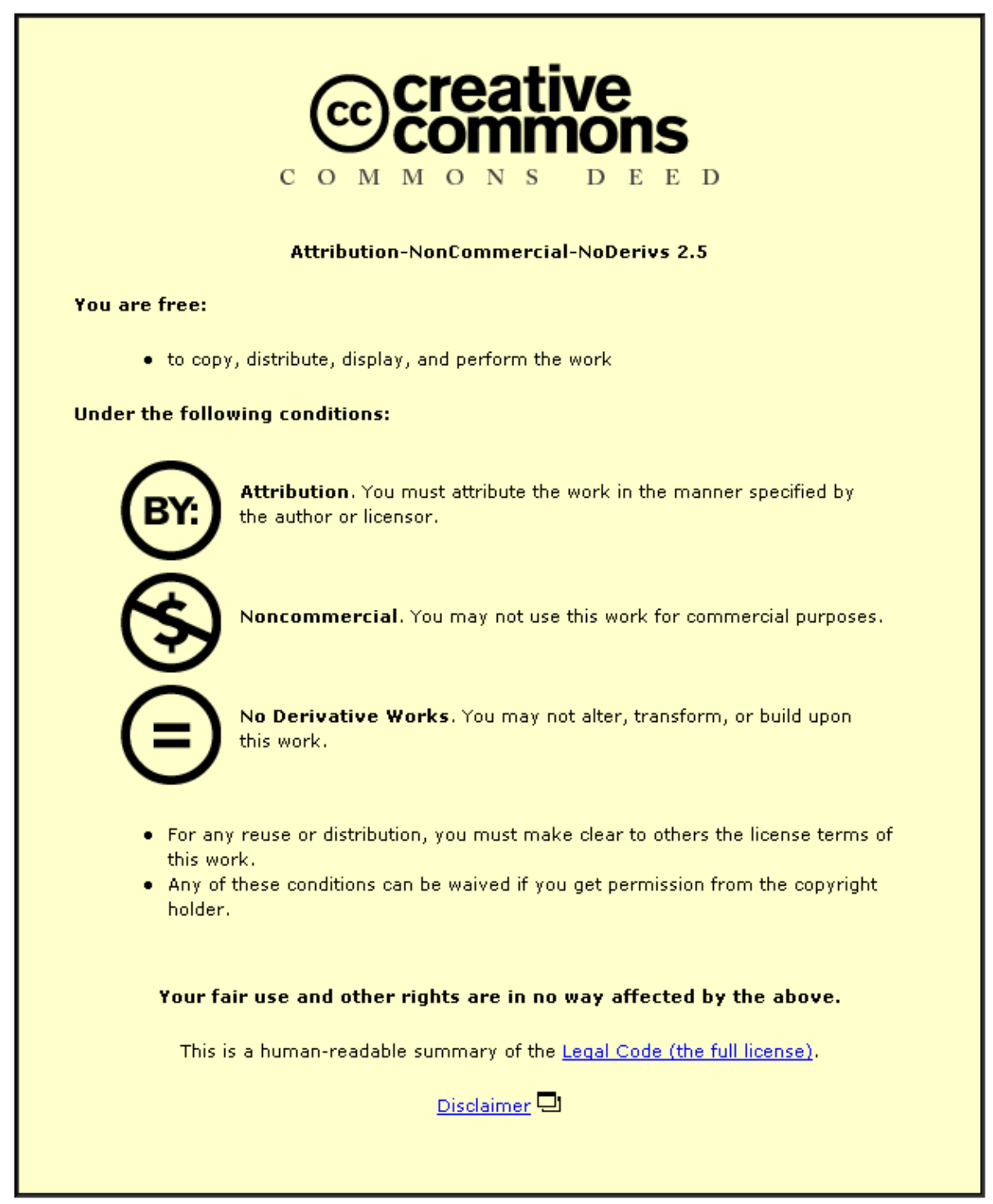

For the full text of this licence, please go to: http://creativecommons.org/licenses/by-nc-nd/2.5/ 
Response of Sphagnum papillosum and Drosera rotundifolia to reduced and oxidised wet $\mathbf{N}$ deposition.

3

4 Jonathan Millett $^{a_{*}}$, Ian D. Leith ${ }^{\text {, }}$, Lucy J. Sheppard ${ }^{\text {b }}$, Jason Newton ${ }^{\text {c }}$

5

6

7

8

9

${ }^{a}$ Centre for Hydrological and Ecosystem Science, Department of Geography, Loughborough University, LE11 3TU, UK

${ }^{\mathrm{b}}$ Center for Ecology and Hydrology, Bush Estate, Penicuik, Midlothian, EH26 0QB, UK

'SUERC, Rankine Avenue, Scottish Enterprise Technology Park, East Kilbride, G75 0QF, UK

*Corrosponding author: email: j.millett@lboro.ac.uk; phone: +44 (0)1509 222739; fax: +44 (0)1509 223930 


\section{Abstract}

We transplanted Sphagnum 'turfs' containing abundant Drosera rotundifolia into an existing nitrogen deposition experiment at Whim Moss near to Edinburgh. These mesocosms received simulated $\mathrm{N}$ deposition in the form of either $\mathrm{NH}_{4}{ }^{+}$or $\mathrm{NO}_{3}{ }^{-}$, to give total $\mathrm{N}$ deposition rates of approximately 8,16 or 32 , or $64 \mathrm{~kg} \mathrm{~N}^{-1}$ year $^{-1}$. Simulated $\mathrm{N}$ deposition was added in a realistic way (i.e. with rainfall throughout the year). The $\delta^{15} \mathrm{~N}$ of this added $\mathrm{N}$ was elevated relative to background $\mathrm{N}$. We measured the tissue chemistry and $\delta^{15} \mathrm{~N}$ of $\mathrm{S}$. papillosum and $D$. rotundifolia over two years after transplant. Our aim was to determine uptake of the deposited $\mathrm{N}$ and the impact on $S$. papillosum tissue chemistry and $D$. rotundifolia tissue chemistry and ecology.

We found clear, significant impacts of $\mathrm{N}$ deposition on $\mathrm{S}$. papillosum, with increased capitula $\mathrm{N}$ content and reduced C:N ratio. Increased $\delta^{15} \mathrm{~N}$ indicated uptake of deposited $N$. The response of $D$. rotundifolia was less clear with impacts only at the highest rate of $\mathrm{N}$ deposition. There was no evidence of differential uptake of reduced or oxidised wet $\mathrm{N}$ deposition by either $\mathrm{S}$. papillosum or $D$. rotundifolia.

Using the natural abundance stale isotope method we estimated the minimum contribution of prey $\mathrm{N}$ to the total $\mathrm{N}$ in $D$. rotundifolia to be $35 \%$.

The results suggest that differences in the uptake of reduced or oxidised wet $\mathrm{N}$ deposition might not be ecologically significant when wet $\mathrm{N}$ deposition is added realistically. They also support the suggestion that a model of $\mathrm{N}$ dynamics in Sphagnum dominated ecosystems that includes the role of Sphagnum as a small scale ecosystem engineer, is required to predict accurately vascular plant responses to $\mathrm{N}$ deposition.

\section{Keywords}

Nitrogen deposition; ombrotrophic bog; carnivorous plants; stable isotopes; nitrogen cycling; global environmental change.

\section{Introduction}

Plant and ecosystem productivity is often limited by nitrogen $(\mathrm{N})$ availability (Vitousek and Howarth, 1991). As such, the deposition of anthropogenic $\mathrm{N}$ emissions can have important long-term impacts on biodiversity and ecosystem function (Galloway et al. 2008; Sala et al. 2000; Vitousek et al. 1997). The largest impacts are expected to occur in the most $\mathrm{N}$ limited ecosystems, because the ability of plants in these ecosystems to respond to increased $\mathrm{N}$ availability is often limited (Bobbink et al. 1998). Species that are better able to utilise the increased $N$ availability will outcompete those that are less able to utilise the increased $\mathrm{N}$, resulting in a loss of the less competitive species. Thus in order to understand plant community responses it is important that we understand how different competing species might respond to increased $\mathrm{N}$ deposition. Furthermore, these responses must be considered under near natural conditions because other biotic and biotic factors might conceivably interact with plant responses to $\mathrm{N}$ availability. 
Plant communities on ombrotrophic bogs are particularly threatened by increases in atmospheric $\mathrm{N}$ deposition, because atmospheric deposition is the only external $\mathrm{N}$ source. As a result, changes in atmospheric $\mathrm{N}$ deposition have substantial impacts on total $\mathrm{N}$ inputs. In the short term the impacts of $\mathrm{N}$ deposition are detectable in plant tissue chemistry and stoichiometry (Skinner et al. 2006). In the longer term these impacts translate into species loss and community change (Bubier et al. 2007). Ombrotrophic bogs are dominated by Sphagnum spp., the capitula of which form a tightly interconnected lawn. This Sphagnum lawn plays an important role in ombrotrophic bog $\mathrm{N}$ dynamics and response to deposition. The Sphagnum capitula absorb atmospheric $\mathrm{N}$ inputs (Williams 1999). The resulting interception and retention by the Sphagnum lawn reduces availability to associated vascular plants (Breeman 1995; Svensson 1995). At higher rates of N deposition the Sphagnum is predicted to become $\mathrm{N}$ saturated and to no longer retain deposited $\mathrm{N}$ (Lamers et al. 2000 ), though $N$ retention by Sphagnum capitula may be reduced even at low levels of $\mathrm{N}$ deposition (Bragazza et al. 2005). Nonetheless, the moderation of $\mathrm{N}$ availability by Sphagnum is predicted to be reduced at higher rates of $\mathrm{N}$ deposition (Heijmans et al. 2002). Therefore, it is important to determine individual species responses to $\mathrm{N}$ deposition when growing within this Sphagnum lawn.

Carnivorous plants capture and extract nutrients from animal prey (Ellison and Gotelli 2001). They are in general restricted to low nitrogen, high light environments due to costs (Carbon) and benefits $(\mathrm{N})$ associated with the carnivorous habit (Ellison and Gotelli 2001; Givnish et al. 1984,). As such, carnivorous plants are common in ombrotrophic bogs. It is predicted that carnivory will become less important as nutrient availability increases, but that due to the cost of carnivory carnivorous plants will be out competed by associated non-carnivorous plants (Ellison and Gotelli 2002). However, there are few studies that have quantified the contribution of prey $N$ to the $\mathrm{N}$ budget of carnivorous plants. Those that have, used the natural abundance stable isotope method (e.g. Schulze et al. 1991, 1997; Moran et al. 2001; Millett et al. 2003). This method allows the estimation of the contribution of prey $N$ to the total $N$ content of carnivorous plants in-situ and with no manipulation of prey or root $\mathrm{N}$ availability. The ${ }^{15} \mathrm{~N}$ natural abundance in carnivorous plants is a result of the ${ }^{15} \mathrm{~N}$ in root derived $\mathrm{N}$ and that in insect derived $\mathrm{N}$. These two sources of $\mathrm{N}$ tend to be distinct in their $\delta^{15} \mathrm{~N}$ signature (i.e. the ratio of ${ }^{14} \mathrm{~N} /{ }^{15} \mathrm{~N}$ relative to that in air), due to ${ }^{15} \mathrm{~N}$ enrichment at higher trophic levels. The natural abundance stable isotope method uses these differences in a simple 2 end-point mixing model to quantify insect and root $\mathrm{N}$ uptake. The $\delta^{15} \mathrm{~N}$ of Sphagnum is also a useful indicator of $\mathrm{N}$ availability and because it closely reflects available $\mathrm{N}$ in the bog and is therefore sensitive to the $\delta^{15} \mathrm{~N}$ of atmospheric inputs.

The carnivorous plant Drosera rotundifolia has a circumboreal distribution and normally, though not exclusively, grows within the Sphagnum lawn in ombrotrophic bogs. Therefore an intricate relationship exists between the responses of these two plants to $\mathrm{N}$ deposition. In this study we transplanted mesocosms consisting of Sphagnum 'turf' containing Drosera rotundifolia from a naturally occurring ombrotrophic bog, into an existing manipulative $\mathrm{N}$ deposition experiment set up on an ombrotrophic bog (Whim Moss) near Edinburgh, UK. The mesocosms were in place for two years with levels of $\mathrm{N}$ deposition (reduced or oxidised) manipulated under realistic conditions (i.e. added throughout the year and concurrently with each rainfall event) with additional $\mathrm{N}$ inputs ranging from 8 to $56 \mathrm{~kg} \mathrm{~N} \mathrm{Ha}^{-1}$. We measured 
115 the response of the Sphagnum and the $D$. rotundifolia in terms of $\delta^{15} \mathrm{~N}, \mathrm{~N}$ content

116 and C:N ratio and aimed to address the following questions: 1. Do S. papillosum and

117 D. rotundifolia differ in their uptake of deposited N? 2. Do differences in levels of

118 deposited $\mathrm{N}$ result in differences in the $\delta^{15} \mathrm{~N}$ signature of the two species? 3 . Is the

119 form of deposited $\mathrm{N}$ (reduced or oxidised) important in determining plant responses

120 to deposition? 4. Is there evidence of decreased reliance on prey derived $\mathrm{N}$ for $D$.

\section{Materials and Methods}

Whim Moss (UK Grid ref NT 203532; N55.77, W-3.27) is an ombrotrophic blanket bog (NVC M19, Rodwell 1991), which is $280 \mathrm{~m}$ a.s.I. and has a gently undulating surface. Annual rainfall is approximately $1000 \mathrm{~mm}$ and mean monthly temperatures range from $5^{\circ} \mathrm{C}$ to $17^{\circ} \mathrm{C}$. Background $\mathrm{N}$ deposition at the site was measured between July 2002 and June 2003. Wet deposition was $5.8 \mathrm{~kg} \mathrm{~N}$ ha $^{-1}$ year ${ }^{-1}$, deposition of $\mathrm{NH}_{3}$ was estimated to be $4.0 \mathrm{~kg} \mathrm{~N} \mathrm{ha}^{-1}$ year ${ }^{-1}$ and other forms of $\mathrm{N}\left(\mathrm{NH}_{4}^{+}\right.$particles, nitric and nitrous acid and $\mathrm{NO}_{\mathrm{x}}$ ) were estimated to be $1.2 \mathrm{~kg} \mathrm{~N} \mathrm{ha}^{-1}$ year $^{-1}$. Therefore total background $\mathrm{N}$ deposition at the site is estimated to be $11 \mathrm{~kg} \mathrm{~N} \mathrm{ha}^{-1}$ year $^{-1}$ but may vary by $1-2 \mathrm{~kg} \mathrm{~N} \mathrm{ha}^{-1}$ year $^{-1}$. The site has received experimental additions of wet $\mathrm{N}$ deposition since July 2002. A full description of the experimental set up can be found in Sheppard et al. (2004) but a summary is provided here. Wet $\mathrm{N}$ deposition treatments were applied throughout the year in parallel to this background deposition and rainfall. This system provides uniquely realistic patterns of $\mathrm{N}$ deposition. Rainfall collected at the study site was mixed with $\mathrm{NH}_{4} \mathrm{Cl}$ or $\mathrm{NaNO}_{3}$ and sprayed onto 12.6 $\mathrm{m}^{2}$ circular plots to achieve total $\mathrm{N}$ depositions of approximately 16,32 and $64 \mathrm{~kg} \mathrm{~N}$ $\mathrm{ha}^{-1}$ year $^{-1}$ (based on estimated background $\mathrm{N}$ deposition of $8 \mathrm{~kg} \mathrm{~N}^{-1}$ year $^{-1}$ prior to the establishment of the experiment). The system was automated and $\mathrm{N}$ was only applied when rainfall occurred and when the wind speed was below $5 \mathrm{~m} \mathrm{~s}^{-1}$. Each plot received the same volume of water (measured using individual water meters), equivalent to an additional $100 \mathrm{~mm}$ of rain per year. Additional control plots received only water additions at the same rate as the other plots. Each of these seven treatments was replicated 4 times in a complete replicate block design. $\mathrm{N}$ additions were made from a bulk chemical supply to ensure that the $\delta^{15} \mathrm{~N}$ of added $\mathrm{N}$ remained constant. The $\delta{ }^{15} \mathrm{~N}$ of added $\mathrm{NH}_{4} \mathrm{Cl}$ and $\mathrm{NaNO}_{3}$ was $-0.68 \%$ o to $-0.58 \%$ ond $+3.1 \%$ to $+4.3 \%$ respectively (Skinner et al. 2006).

In September 2007 mesocosms (38 cm x $24 \mathrm{~cm}$ and $5 \mathrm{~cm}$ deep) consisting of Sphagnum 'turfs' dominated by S. papillosum with abundant Drosera rotundifolia were transplanted into each of the 28 experimental plots. The turfs were removed from a mire with typical NVC M15 vegetation, (Rodwell 1991) next to Glenbrittal Youth Hostel on the Isle of Skye (UK Grid REF: NG409225; N: $57.22^{\circ}$, W: $-6.29^{\circ}$ ). This wet heath exhibits a hummock-hollow-pool topography and is dominated by Molinia caerulea, Scirpus cespitosus, Erica tetralix and Calluna vulgaris. Drosera rotundifolia was present mainly in the more open areas next to pools, and this is where turfs were collected. Each turf was placed into a hole of the same dimensions on the edge of each plot. All turfs were placed at the eastern side of the plot to remove the potential for differences due to spray drift. A sample of $D$. rotundifolia growing in each mesocosm was taken in May 2008 and in August of 2008 and 2009. This consisted of the shoots and roots (excluding the remains of previous year's growth) of 4 individual $D$. rotundifolia plants per plot. In addition, a sample of $S$. 
papillosum capitula consisting of the capitula of at least 10 individual S. papillosum plants was taken in August 2008 and August 2009. At the same time that plant material was collected in August a sample of available insect prey was also collected. This is so that an assessment could be made of the ${ }^{15} \mathrm{~N}$ natural abundance of the insect prey captured by $D$. rotundifolia. Insects were captured on sticky yellow insect traps left on each plot for 24 hours. Only insects $<2 \mathrm{~mm}$ were used for this sample, reflecting the likely size of prey.

The plant samples were rinsed in de-ionised water and any contaminating debris was removed. All samples were then dried at $70^{\circ} \mathrm{C}$ for 72 hours. D. rotundifolia plants were then weighed. All plant material was milled to a fine powder in a ball mill, insects were ground using a pestle and mortar. The $\delta^{15} \mathrm{~N}$ of all tissues was analysed using a Carlo-Erba elemental analyser linked to a Dennis Leigh Technologies IRMS. Results are given using the $\delta$ notation expressed in units of per mil (\%o) where $\delta=$ $\left(R_{\text {sample }} / R_{\text {reference }}\right)-1 \times 1000$, and $R={ }^{15} \mathrm{~N}:{ }^{14} \mathrm{~N}$. Data are reported with respect to $\mathrm{N}$ in air. $\% \mathrm{~N}$ and $\mathrm{C}: \mathrm{N}$ ratios are determined from the output of this analysis.

The contribution of insect derived $\mathrm{N}$ to the total $\mathrm{N}$ content of $D$. rotundifolia was calculated in using a simple two end-point mixing model as follows (following Millett et al. 2003):

$$
\% N_{\text {dfp }}=\left(\delta^{15} N_{\text {DROSERA }}-\delta^{15} N_{\text {REF }}\right) /\left(\delta^{15} N_{\text {INSECT }}-\delta^{15} N_{\text {REF }}\right)
$$

Where, $\% \mathrm{~N}_{\text {dfp }}$ is the proportion of $\mathrm{N}$ derived from insect prey, $\delta^{15} \mathrm{~N}_{\text {DROSERA }}$ is the $\delta^{15} \mathrm{~N}$ of the $D$. rotundifolia plants, $\delta^{15} \mathrm{~N}_{\mathrm{REF}}$ is the $\delta^{15} \mathrm{~N}$ of either the capitula of the Sphagnum in which the $D$. rotundifolia is growing or the lowest $\delta^{15} \mathrm{~N}$ of individual $D$. rotundifolia plants in each treatment in 2008, and $\delta^{15} N_{\text {INSECT }}$ is the $\delta^{15} \mathrm{~N}$ of the sample of the insects available as prey. The use of the lowest value of $\delta^{15} \mathrm{~N}$ for $D$.

rotundifolia enables the minimum $\% \mathrm{~N}_{\text {dfp }}$ to be estimated, assuming that the $\delta^{15} \mathrm{~N}$ of this plant is lowest because $\% \mathrm{~N}_{\text {dfp }}$ is lower than all other $D$. rotundifolia plants (but may not be zero). Two different values for $\delta^{15} \mathrm{~N}_{\mathrm{REF}}$ were used to enable the reliability of using $S$. papillosum to be tested.

Data were analysed using GLM in SPSS (SPSS 2008). A repeated measures model was used for summer 2008 and summer 2009 plant data. Measures of $D$. rotundifolia characteristics in 2008 were analysed using a univariate GLM model. Differences in $\delta{ }^{15} \mathrm{~N}$ between $D$. rotundifolia, S. papillosum and captured insects were tested using a repeated measures GLM.

\section{Results}

There was a clear and consistent increase in $\delta^{15} \mathrm{~N}$ and $\mathrm{N}$ content and a decrease in $\mathrm{C}: \mathrm{N}$ of $\mathrm{S}$. papillosum tissues as a result of increasing $\mathrm{N}$ deposition (Fig. 1, Table 1). These impacts were statistically significant at $\mathrm{N}$ addition rates of more than $16 \mathrm{~kg} \mathrm{~N}$ $\mathrm{ha}^{-1}$ year $^{-1}$. This pattern was consistent for both years, though between 2008 and 2009 there was an overall decrease in mean C:N (from 36.1 \pm 1.1 to $32.7 \pm 1.2$ ) and $\delta^{15} \mathrm{~N}$ (from $-1.78 \pm 0.18$ to $-1.07 \pm 0.17$ ) with no significant change in $\mathrm{N}$ content. Sphagnum papillosum receiving dditional $\mathrm{N}$ deposition as $\mathrm{NO}_{3}$ had slightly higher $\delta^{15} \mathrm{~N}$ than those receiving additional $\mathrm{N}$ deposition as $\mathrm{NH}_{4}$, while those receiving just 
214 ambient $\mathrm{N}$ deposition had lower $\delta^{15} \mathrm{~N}$ than both these treatments (Fig. 2). However,

The response of $D$. rotundifolia to the $\mathrm{N}$ addition treatments was different to that of $S$. papillosum. $\delta^{15} \mathrm{~N}$ of $D$. rotundifolia tissues did not differ between $\mathrm{N}$ addition treatments. Furthermore, there was no clear trend in tissue percent $\mathrm{N}$ and $\mathrm{C}: \mathrm{N}$ ratio for plants growing at lower $\mathrm{N}$ additions $\left(<64 \mathrm{~kg} \mathrm{~N}^{-1}\right.$ year $\left.{ }^{-1}\right)$. However, at $\mathrm{N}$ additions of over $32 \mathrm{~kg} \mathrm{~N} \mathrm{ha}^{-1}$ year $^{-1}$ there was a significant increase in tissue percent $\mathrm{N}$ content and decrease in $\mathrm{C}: \mathrm{N}$ ratio. This pattern was also consistent in both years, though there was an increase in percent $N$ content (from $1.54 \pm 0.05 \%$ to $1.78 \pm 0.06 \%$ ) and a decrease in C:N (from $31.4 \pm 0.9$ to $27.4 \pm 0.9$ ) between 2008 and 2009. There was no significant difference between $\delta^{15} \mathrm{~N}$ of $D$. rotundifolia in 2008 and 2009. $\delta^{15} \mathrm{~N}$ of $D$. rotundifolia plants was significantly affected by the form of additional wet $\mathrm{N}$ deposition added to plots with those receiving $\mathrm{NO}_{3}$ having a higher $\delta^{15} \mathrm{~N}$ than those receiving $\mathrm{NH}_{4}$ (Fig. 2).

On average the dry mass of $D$. rotundifolia plants increased from $5.0 \pm 0.4 \mathrm{mg}$ to $15.0 \pm 1.0 \mathrm{mg}$ from spring 2008 to summer 2008 . The percent content of $\mathrm{N}$ in the plant tissue decreased from $2.53 \pm 0.10 \%$ to $1.56 \pm 0.05 \%$ and $\mathrm{N}$ content increased from $0.13 \pm 0.01$ to $0.23 \pm 0.01 \mathrm{mg} \mathrm{N}$ plant $^{-1}$. There was no change in mass between summer 2008 and summer 2009, but there was a relatively small but significant increase in tissue $\mathrm{N}$ percent content to $1.76 \pm 0.06 \%$ and as a result an increase in total plant $\mathrm{N}$ content to $0.26 \pm 0.02 \mathrm{mg} \mathrm{N}$ plant $^{-1}$. Between 2008 and 2009 there was an increase in rosette diameter (from $19.6 \pm 0.71$ to $22.8 \pm 1.22 \mathrm{~mm}$ ) and the number of leaves per plant (from $3.66 \pm 0.13$ to $5.69 \pm 0.65$ ). Plant mass and total plant $N$ content did not differ between $\mathrm{N}$ addition treatments in either 2008 or 2009.

$21.4 \pm 2.4 \%$ and $7.6 \pm 1.5 \%$ of all $D$. rotundifolia leaves contained trapped prey at the time of sampling in 2008 and 2009 respectively. On average $0.85 \pm 0.09$ and $0.41 \pm 0.09$ trapped insects were found on each plant in 2008 and 2009 respectively. Significantly more insects were present in traps and a larger proportion of leaves contained trapped prey in 2008 but there was no significant difference between treatments. The mean $\delta^{15} \mathrm{~N}$ of collected insects was $4.38 \pm 0.33 \%$. The $\delta^{15} \mathrm{~N}$ of trapped insects differed significantly in each year but not between treatments (Fig. 3). Considering all the $\delta^{15} \mathrm{~N}$ data together there were significant differences in the $\delta^{15} \mathrm{~N}$ of $D$. rotundifolia, $S$. papillosum and trapped insects (GLM: $F=50.135, P<0.001$; Fig. 3). The average minimum $\delta^{15} \mathrm{~N}$ of individual $D$. rotundifolia plants in 2008 was significantly lower than that of S. papillosum in 2008 and 2009 and the mean $\delta^{15} \mathrm{~N}$ of $D$. rotundifolia in 2008 and 2009 (Fig. 3). Insect $\delta^{15} \mathrm{~N}$ was higher than that of all $D$. rotundifolia and S. papillosum plants. When these differences in $\delta^{15} \mathrm{~N}$ were used to estimate $\mathrm{N}_{\mathrm{dfp}}$, the $D$. rotundifolia plants were estimated to have obtained either $10 \pm 3.2 \%$ and $17 \pm 18.9 \%$ (using $\delta^{15} \mathrm{~N}$ of $S$. papillosum as the reference value in 2008 and 2009 respectively) or a minimum of $29 \pm 2.2 \%$ and $42 \pm 5.9 \%$ (using the lowest value of $\delta^{15} \mathrm{~N}$ for $D$. rotundifolia as the reference value in 2008 and 2009 respectively).

\section{Discussion}

This is the first field-based experimental $\mathrm{N}$ deposition study where $\mathrm{N}$ is added in a realistic way (i.e. throughout the year and concurrently with rainfall events). As such 
we can be confidant that plant responses represent that expected in-situ. There is clear evidence that $S$. papillosum took up and incorporated deposited $\mathrm{N}$ into its tissues. This resulted in increased $\delta^{15} \mathrm{~N}$ due to the distinct $\delta^{15} \mathrm{~N}$ signature of the added $\mathrm{N}$. This increased $\mathrm{N}$ uptake resulted in increased tissue $\mathrm{N}$ percent content and reduced $\mathrm{C}: \mathrm{N}$ ratio of $\mathrm{S}$. papillosum plant tissue. This response supports previous studies that have demonstrated the incorporation of experimentally added $\mathrm{N}$ along a range of addition rates (e.g. Soares and Pearson 1997) and changes along gradients of $\mathrm{N}$ deposition (Bragazza et al. 2005). These impacts were statistically significant at levels of $\mathrm{N}$ deposition above $16 \mathrm{~kg} \mathrm{~N}^{-1} \mathrm{year}^{-1}$. This is consistent with the model proposed by Lamers et al. (2000), who suggested that at $\mathrm{N}$ deposition rates between 12-18 kg N ha ${ }^{-1}$ year $^{-1} \mathrm{~N}$ percent content in the tissue of Sphagnum would increase. However, Bragazza et al. (2005) and Jiroušek et al. (2011) found that under long term $\mathrm{N}$ deposition of more than $10 \mathrm{~kg} \mathrm{~N} \mathrm{ha}^{-1}$ year $^{-1}$ there is no impact of increasing $\mathrm{N}$ deposition on Sphagnum tissue $\mathrm{N}$ content. Our results are not inconsistent with these previous studies. Sphagnum capitula N content in our study (1.10 to $1.60 \%)$ are not qualitatively different to those of Bragazza et al. (2005) (approx. 1.19\%) or Jiroušek et al. (2011) (1.07 to 1.67\%) at similar levels of $\mathrm{N}$ deposition. It might be expected that there will be a time-lag between the addition of $\mathrm{N}$ and the saturation of plant tissues, and that this time-lag will be longer under lower levels of $\mathrm{N}$ deposition. Therefore, in our 2-year study the measurements might reflect differences in the rate of change rather than final tissue $\mathrm{N}$ concentrations per se.

The impact of $\mathrm{N}$ deposition on $D$. rotundifolia tissue $\mathrm{N}$ percent and $\mathrm{C}: \mathrm{N}$ ratio was only significant at the highest rates of input (i.e. $>32 \mathrm{~kg} \mathrm{~N} \mathrm{ha}^{-1}$ year $^{-1}$ ). Presumably this is due to some $\mathrm{N}$ saturation in $\mathrm{S}$. papillosum or at least due to uptake by S. papillosum being slower than deposition at these higher levels of $\mathrm{N}$ deposition. Lamers et al. (2000) suggested that deposited $\mathrm{N}$ would only become available to co-occurring plants above $18 \mathrm{~kg} \mathrm{~N}^{-1}$ year $^{-1}$. Our findings support this, at least for $D$. rotundifolia. Sphagnum has previously been shown to intercept and store added $\mathrm{N}$ making the $\mathrm{N}$ unavailable to co-occurring $D$. rotundifolia (Svensson 1995). This appears to be the case in the present study and is consistent with the role of Sphagnum as a small scale ecosystem engineer. However, Sphagnum might not necessarily absorb all deposited $\mathrm{N}$. If this is the case in the present study then additional $\mathrm{N}$ availability was not high enough to result in changes in $D$. rotundifolia growth and physiology until $\mathrm{N}$ deposition was above $32 \mathrm{~kg} \mathrm{~N} \mathrm{ha}^{-1}$ year $^{-1}$.

Differential uptake of $\mathrm{NH}_{4}{ }^{+}$and $\mathrm{NO}_{3}{ }^{-}$by Sphagnum spp. has been demonstrated in glasshouse studies, with preferential uptake of $\mathrm{NH}_{4}^{+}$(Jauhiainen et al. 1998; Wiederman et al. 2009). The implication is that Sphagnum spp. will be differently affected by deposition of $\mathrm{NH}_{4}{ }^{+}$and $\mathrm{NO}_{3}{ }^{-}$. The present study provides an ideal opportunity to test the significance of this differential uptake, in a system receiving $\mathrm{N}$ deposition in a realistic manner. The patterns of $\delta^{15} \mathrm{~N}$ of the S. papillosum and $D$. rotundifolia followed that of their potential $\mathrm{N}$ sources. Those in the controls had lowest $\delta^{15} \mathrm{~N}$, those receiving $\mathrm{NH}_{4}{ }^{+}$had intermediate tissue $\delta^{15} \mathrm{~N}$ values and those receiving $\mathrm{NO}_{3}{ }^{-}$had the highest tissue $\delta^{15} \mathrm{~N}$ values. These differences probably reflect the lower $\delta^{15} \mathrm{~N}$ of rain water (not measured in the present study but generally ${ }^{15} \mathrm{~N}$ depleted - Heaton 1986, Freyer 1978), the intermediate $\delta^{15} \mathrm{~N}$ of the added $\mathrm{NH}_{4} \mathrm{Cl}(-$ $0.68 \%$ to $-0.58 \%$ o ) and the higher $\delta^{15} \mathrm{~N}$ of the added $\mathrm{NaNO}_{3}(+3.1 \%$ o to $+4.3 \%$ o $)$. This indicates little difference in the uptake of $\mathrm{N}$ from these different sources, which would have resulted in patterns of $\delta^{15} \mathrm{~N}$ that differed from that of the added $\mathrm{N}$. This is further 
supported by the lack of impact of $\mathrm{N}$ type on any of the measurements except for $\delta^{15} \mathrm{~N}$. The discrepancy in the results of previous studies and the present study may be due to the way in which the $\mathrm{N}$ is added in the present study. This may mean that the results from previous ex-situ studies do not translate into measurable impacts where simulated $\mathrm{N}$ deposition is added in a realistic way. This may be because the differences are short lived as was shown by Pearce and Van der Wal (1999) for Racomitrium lanuginosum. However, the uptake and impact of different forms of $\mathrm{N}$ by bryophytes is species specific (Paulissen et al. 2005), making it difficult to compare between studies.

There was no significant impact of $\mathrm{N}$ addition on $\delta^{15} \mathrm{~N}$ of $D$. rotundifolia, as would have been expected if the plants took up any of the added $\mathrm{N}$. This could be due to a number of reasons. It might be the case that the additional $\mathrm{N}$ provided by the deposition treatments was not available to the $D$. rotundifolia plants because it was intercepted by the Sphagnum before they were able to access the $\mathrm{N}$, as has been shown by Svensson (1995). Alternatively the $D$. rotundifolia plants may have taken up the added $\mathrm{N}$ but the change in $\delta^{15} \mathrm{~N}$ was offset by a reduction in prey capture (i.e. the elevated $\delta^{15} \mathrm{~N}$ of the prey would then contribute less to the $\delta^{15} \mathrm{~N}$ of the $D$. rotundifolia). There is further evidence to support this second scenario. The differences in $\delta^{15} \mathrm{~N}$ of $D$. rotundifolia reflected those in the added $\mathrm{N}$. This strongly suggests that the $D$. rotundifolia plants were taking up the added $\mathrm{N}$. A reduction in prey capture when $\mathrm{N}$ deposition was higher would be expected because the investment in prey capture has a lower relative benefit at higher $\mathrm{N}$ availabilities (Givnish et al. 1986). Additionally, reduced investment in carnivory by $D$. rotundifolia when root $\mathrm{N}$ availability is high has been shown by Thorén et al. (2003). Therefore, we tentatively suggest that this was the case for the $D$. rotundifolia plants in our study. However, this cannot be confirmed with the data we collected, in part due to the difficulty in our study in determining the proportion of $\mathrm{N}$ derived from prey $\left(\% \mathrm{~N}_{\mathrm{dfp}}\right)$ using the natural abundance stable isotope method.

Where there are sufficient differences in the $\delta^{15} \mathrm{~N}$ of root derived $\mathrm{N}$ and prey derived $\mathrm{N}, \% \mathrm{~N}_{\text {dfp }}$ can be calculated by using the $\delta^{15} \mathrm{~N}$ signature of the carnivorous plant, a sample of potential prey and associated non-carnivorous plants (e.g. Schulze et al. 1991, Schulze et al. 1997, Millett et al. 2003). This approach is the same as that proposed by Shearer and Kohl (1986) and used widely to estimate the proportion of $\mathrm{N}_{2}$ derived from atmospheric fixation in $\mathrm{N}_{2}$-fixing plants. For any use of this natural abundance stable isotope mehod the choice of references for the two end-points is central to the accuracy of the model (Boddey et al. 2000, Unkovich et al. 2008). When estimating $\mathrm{N}_{\text {dfp }}$ the two end points represent carnivorous plants that have obtained all or none of their $\mathrm{N}$ from insect prey. The use of a sample of potential or actual prey has been universally adopted for the former. This assumes that the $\delta^{15} \mathrm{~N}$ of $\mathrm{N}$ taken up from digested prey is the same as the $\delta^{15} \mathrm{~N}$ of the entire insect. However, carnivorous plants do not take up all $\mathrm{N}$ contained in their insect prey. For example, Hanslin and Karlsson (1996) found that Pinguicula spp. and D. rotundifolia took up between 29 and $42 \%$ of the $\mathrm{N}$ contained in insect prey. If this uptake is not evenly distributed between insect tissues, or if there is fractionation of ${ }^{15} \mathrm{~N}$ during assimilation, the $\delta^{15} \mathrm{~N}$ of prey derived $\mathrm{N}$ may differ from that of the prey.

Nonetheless, these differences are likely to be small relative to the large difference between insect $\delta^{15} \mathrm{~N}$ and the $\delta^{15} \mathrm{~N}$ of the target carnivorous plant. As such, the use of insects should provide a reasonable approximation of the $\delta^{15} \mathrm{~N}$ of $\mathrm{N}$ taken up from 
prey, as long as the species composition used is representative of that of actual prey capture.

Different approaches have been taken to estimating $\delta^{15} \mathrm{~N}$ of carnivorous plants that obtain no N from prey capture. Schulze et al. (1991) and Moran et al. (2001) used non-carnivorous vascular plants growing close to their target carnivorous plants. Millett et al. (2003) used both the Sphagnum that was the substrate for the target carnivorous plants and non-carnivorous vascular plants growing in close proximity. They found differences in $\delta^{15} \mathrm{~N}$ as large as $1.4 \%$ between the Sphagnum and noncarnivorous vascular plants. Schulze et al. (1997) used non-trapping laves of the target carnivorous plant as references for this end point, though this assumes no transfer of prey derived $\mathrm{N}$ between tissues. In the present study, we used two different reference plants: the $S$. papillosum that was the substrate for the $D$. rotundifolia plants and the lowest $\delta^{15} \mathrm{~N}$ of $D$. rotundifolia plants. It was not possible to use co-occurring non-carnivorous vascular plants because the turfs were transplanted without these. The use of the minimum $D$. rotundifolia $\delta^{15} \mathrm{~N}$ probably provides an accurate minimum $\% \mathrm{~N}_{\text {dfp. }}$. This is because issues regarding the requirements of similarity in root $\mathrm{N}$ sources and in ${ }^{15} \mathrm{~N}$ fractionation are eliminated by using the same species. Millett et al. (2003) found that the D. rotundifolia with the lowest $\delta^{15} \mathrm{~N}$ had $\delta^{15} \mathrm{~N}$ values almost identical to that of the Sphagnum in which they were growing. This indicates that in their study the use of either of these two methods would give similar values for $\% \mathrm{~N}_{\text {dfp }}$, and shows that both were suitable. However, in the present study the values for $\% \mathrm{~N}_{\text {dfp }}$ calculated using $S$ papillosum as the reference species (on average $13 \%$ ) considerably underestimated $\% \mathrm{~N}_{\text {dfp }}$. The estimate for $\% \mathrm{~N}_{\text {dfp }}$ was lower than the minimum inferred from using the lowest $D$. rotundifolia $\delta^{15} \mathrm{~N}$ (on average $35 \%$ ). Therefore, we must conclude that in the present study S. papillosum is not a suitable reference species for calculating $\% \mathrm{~N}_{\text {dfp }}$. The reasons for this probably relate to the ex-situ nature of this study, resulting in complex ${ }^{15} \mathrm{~N}$ sources and interactions between $\mathrm{N}$ deposition, $S$. papillosum and $D$. rotundifolia $\mathrm{N}$ uptake in a system that had not yet reached equilibrium. We suggest that care should be taken when using the natural abundance method to estimate $\% \mathrm{~N}_{\mathrm{dfp}}$ for carnivorous plants in ex-situ studies. As a result we can only conclude that the $D$. rotundifolia plants in our study obtained on average a minimum of $35 \%$ of their $\mathrm{N}$ from prey. This is consistent with previous studies (e.g. $50 \%$ for $D$. rotundifolia in the UK found by Millett et al. 2003).

We conclude that the $D$. rotundifolia in this study obtained a significant proportion of their $\mathrm{N}$ budget from their insect prey, but it was not possible to determine the impact of $\mathrm{N}$ deposition on this $\mathrm{N}$ source. S. papillosum in this study intercepted and stored deposited $\mathrm{N}$ resulting in increased tissue $\mathrm{N}$ concentration and decreased $\mathrm{C}: \mathrm{N}$ ratio. Drosera rotundifolia was relatively unaffected by the increased $\mathrm{N}$ deposition, though there was some evidence of increased tissue $\mathrm{N}$ concentration at the highest $\mathrm{N}$ deposition rates $\left(64 \mathrm{~kg} \mathrm{~N} \mathrm{ha}^{-1}\right.$ year $\left.^{-1}\right)$. These contrasting responses may be because of the alternative (prey) $\mathrm{N}$ source of $D$. rotundifolia or because Sphagnum acts as a small scale ecosystem engineer at lower $\mathrm{N}$ deposition rates. Furthermore, this study shows that even after only two years of $\mathrm{N}$ addition, wet $\mathrm{N}$ deposition with a distinct ${ }^{15} \mathrm{~N}$ signature can be traced in $S$. papillosum but not $D$. rotundifolia. Finally, the plants in this study system showed no discernable difference in response to reduced or oxidised forms of wet $\mathrm{N}$ deposition. There was also no evidence of differential uptake of deposited $\mathrm{N}$ when added in reduced or oxidised form. This suggests that, 
414 in the short term at least, it is the amount of wet $\mathrm{N}$ deposition and not the form of

415 deposited $\mathrm{N}$ that is most important in terms of plant response.

\section{Acknowledgements}

418 This research was funded by a grant from the British Ecological Society (grant number 713/1414) and benefit-in-kind funding from the UK Natural Environment

Research Council, Life Sciences Mass Spectrometry Facility (grant number EK11308/07).

\section{References}

Bobbink R (1998) Impacts of tropospheric ozone and airborne nitrogenous pollutants on natural and semi-natural ecosystems: a commentary. New Phytologist 139:161168

428 Boddey RM, Peoples MB, Palmer B, Dart PJ (2000) Use of the ${ }^{15} \mathrm{~N}$ natural abundance technique to quantify biological nitrogen fixation by woody perennials. Nutr. Cycl. Agroecosys. 57:235-270

Bragazza L, Limpens J, Gerdol R, Grosvernier P, Hájek M, Hájek T, Hájková P, Hansen I, Lacumin P, Kutnar L, Rydin H, Tahvanainen T ( 2005) Nitrogen concentration and $\delta^{15} \mathrm{~N}$ signature of ombrotrophic Sphagnum mosses at different $\mathrm{N}$ deposition levels in Europe. Global Change Biology 11:106-114

Breemen N (1995) How Sphagnum bogs down other plants. Trends in Ecology \& Evolution 10:270-275

Bubier J, Moore T, Bledzki LA (2007) Effects of nutrient addition on vegetation and carbon cycling in an ombrotrophic bog. Global Change Biology 13:1168-1186

439 Ellison AM, Gotelli NJ (2001) Evolutionary ecology of carnivorous plants. Trends in Ecology and Evolution 16:623-629

441 Ellison AM, Gotelli NJ (2002) Nitrogen availability alters the expression of carnivory in the northern pitcher plant, Sarracenia purpurea. Proceedings of the National Academy of Sciences 99:4409-4412

444 Freyer $\mathrm{HD}(1978)$ Seasonal trends of $\mathrm{NH}_{4}{ }^{+}$and $\mathrm{NO}_{3}{ }^{-}$nitrogen isotope composition in rain collected at Jullich, Germany. Tellus 30:83-92

446 Galloway JN, Townsend AR, Erisman JW, Bekunda M, Cai Z, Freney JR, Martinelli, 447 LA, Seitzinger SP, Sutton MA, (2008) Transformation of the nitrogen cycle: recent 448 trends, questions, and potential solutions. Science 320:889-892

449 Givnish TJ, Burkhardt EL, Happel RE, Weintraub JD (1984) Carnivory in the 450 bromeliad Brocchinia reducta, with a cost/benefit model for the general restriction of 451 carnivorous plants to sunny, moist nutrient-poor habitats. American Naturalist 452 124:479-497

453 Hanslin HM, Karlsson PS (1996) Nitrogen uptake from prey and substrate as 454 affected by prey capture level and plant reproductive status in four carnivorous plant 
species. Oecologia 106:370-375

Heaton THE (1986) Isotopic studies of nitrogen pollution in the hydrosphere and atmosphere: a review. Chemical Geology 59:87-102

Heijmans MMPD, Klees H, de Visser W, Berendse F (2002) Effects of increased nitrogen deposition on the distribution of ${ }^{15} \mathrm{~N}$-labeled nitrogen between Sphagnum and vascular plants. Ecosystems 5:500-508

Jauhiainen J, Wallén B, Malmer $\mathrm{N}$ (1998) Potential $\mathrm{NH}_{4}{ }^{+}$and $\mathrm{NO}_{3}{ }^{-}$uptake in seven Sphagnum species. New Phytologist 138:287-293

Jiroušek M, Hájek M, Bragazza L (2011) Nutrient stoichiometry in Sphagnum along a nitrogen deposition gradient in highly polluted region of Central-East Europe.

Environmental Pollution 159:585-590

Lamers LPM, Bobbink R, Roelofs JGM (2000) Natural nitrogen filter fails in polluted raised bogs. Global Change Biology 6:583-586

Leith ID, Sheppard LJ, Fowler D, Cape NJ, Jones M, Crossley KJ, Hargreaves S, Tang YS, Theobald M, Sutton MA (2004) Quantification of dry N deposition to an ombrotrophic bog from an automated $\mathrm{NH}_{3}$ release system. Water, Air, and Soil Pollution 6:207-218

Leith ID, Sheppard LJ, Pitcairn CER, Cape JN, Hill PW, Kennedy VH, Tang YS, Smith RI, Fowler D (2001) Comparison of the effects of wet $\mathrm{N}$ deposition $\left(\mathrm{NH}_{4} \mathrm{Cl}\right)$ and dry $\mathrm{N}$ deposition $\left(\mathrm{NH}_{3}\right)$ on UK moorland species. Water, Air, and Soil Pollution 130:1043-1048

Millett J, Jones RI, Waldron S (2003) The contribution of insect prey to the total nitrogen content of sundews (Drosera spp.) determined in situ by stable isotope analysis. New Phytologist 158:527-534

Moran JA, Merbach MA, Livingston NJ, Clarke CM, Booth WE (2001) Termite prey specialization in the pitcher plant Nepenthes albomarginata - evidence from stable isotope analysis. Annals of Botany 88:307-311

Paulissen MPCP, Besalú LE, Bruijn H de, Van der Ven PJM, Bobbink R (2005) Contrasting effects of ammonium enrichment on fen bryophytes. Journal of Bryology 27:109-117

Pearce ISK, van der Wal R (2002) Effects of nitrogen deposition on growth and survival of montane Racomitrium lanuginosum heath. Biological conservation 104:83-89

Rodwell JS (1991) Mires and Heaths, British Plant Communities. Cambridge University Press, Cambridge, UK.

Sala OE, Chapin III FS, Armesto JJ, Berlow R, Bloomfield J, Dirzo R, HuberSanwald E, Huenneke LF, Jackson RB, Kinzig A, Leemans R, Lodge D, Mooney, HA, Oesterheld M, Poff, NL, Sykes MT, Walker BH, Walker M, Wall DH, (2000) Global biodiversity scenarios for the year 2100 . Science $287: 1770-1774$ 
Schulze ED, Gebauer G, Schulze W, Pate JS (1991) The utilization of nitrogen from insect capture by different growth forms of Drosera from Southwest Australia.

Schulze W, Schulze ED, Pate JS, Gillison AN (1997) The nitrogen supply from soils and insects during growth of the pitcher plants Nepenthes mirabilis, Cephalotus follicularis, and Darlingtonia californica. Oecologia 112:464-471

500 Shearer GB, Kohl DH (1986) $\mathrm{N}_{2}$ - fixation in field settings: estimations based on natural ${ }^{15} \mathrm{~N}$ abundance. Aust. J. Plant Physiol. 13:699-756

502

503

504

505

506

507

508

Sheppard LJ, Leith ID, Crossley A, Carfrae JA, Elix J, Tang YS, Blackall T, Jones, M, Theobald M, Hargreaves K, Cape NJ, Fowler D, Raven J (2004) Rapid responses of an ombrotrophic bog community to $\mathrm{N}$ enrichment: discrimination between different forms. Water, Air, and Soil Pollution 6:197-205

Skinner RA, Ineson P, Jones H, Sleep D, Leith ID, Sheppard LJ, (2006) Heathland vegetation as a bio-monitor for nitrogen deposition and source attribution using $\delta^{15} \mathrm{~N}$ values. Atmospheric Environment 40:498-507

Soares AS, Pearson J (1997) Short-term physiological responses of mosses to atmospheric ammonium and nitrate. Water, Air, and Soil Pollution 93:225-242

SPSS (2008) SPSS Statistics 17.0. Release 17.0.0 (Aug 23, 2008).

Svensson BM (1995) Competition between Sphagnum fuscum and Drosera rotundifolia: a case of ecosystem engineering. Oikos 74:205-212

Thorén LM, Tuomi J, Kämäräinen T, Laine K. (2003) Resource availability affects investment in carnivory in Drosera rotundifolia.

Unkovich M, Herridge DF, Peoples MB, Boddey RM, Cadisch G, Giller K, Alves B, Chalk PM (2008) Measuring plant-associated nitrogen fixation in agricultural systems. ACIAR Monograph No.136. Canberra: Australian Centre for International Agricultural Research.

Vitousek PM, Aber JD, Howarth RW, Likens GE, Matson PA, Schindler DW, Schlesinger WH, Tilman DG (1997) Human alteration of the global nitrogen cycle: sources and concequences. Ecological Applications 7:737-750

Vitousek PM, Howarth RW (1991) Nitrogen limitation on land and in the sea: How can it occur? Biogeochemistry 13:87-115

Wiedermann MM, Gunnarsson U, Ericson L, Nordin A (2009) Ecophysiological adjustment of two Sphagnum species in response to anthropogenic nitrogen deposition. New Phytologist 181:208-217

Williams B, Silcock D, Young M (1999) Seasonal dynamics of N in two Sphagnum moss species and the underlying peat treated with ${ }^{15} \mathrm{NH}_{4}{ }^{15} \mathrm{NO}_{3}$. Biogeochemistry 45:285-302 


\section{Tables}

\section{Table 1}

534 Significance of Repeated Measures GLM for characteristics of $D$. rotundifolia and S.

535 papillosum growing in microcosms transplanted into the Whim Moss $\mathrm{N}$ deposition

536 Experiment. Presented are the d.f. and $P$ values for the effect of level of $\mathrm{N}$ deposition

537 (4 levels) type of $\mathrm{N}$ deposition (3 levels) and years of measurement (2 levels). All 2

538 and 3-way interactions were non-significant and are therefore excluded.

\begin{tabular}{llll}
\hline & N level & $\mathrm{N}$ type & Year \\
\cline { 2 - 4 } d.f. & 2,20 & 1,20 & 1,20 \\
\hline D. rotundifolia & & & \\
$\mathrm{N} \%$ & $\mathbf{0 . 0 0 4}$ & 0.42 & $\mathbf{0 . 0 2}$ \\
$\mathrm{C}: \mathrm{N}$ & $\mathbf{0 . 0 0 2}$ & 0.49 & $\mathbf{0 . 0 1}$ \\
$\delta^{15} \mathrm{~N}$ & 0.38 & $\mathbf{0 . 0 5}$ & 0.69 \\
Mass/plant & 0.17 & 0.10 & 1.00 \\
Total N/plant & 0.31 & 0.30 & 0.39 \\
Rosette diameter & 0.38 & 0.77 & $\mathbf{0 . 0 1}$ \\
Number of leaves/plant & 0.34 & 0.12 & $\mathbf{0 . 0 0 3}$ \\
Number of leaves with & 0.14 & 0.22 & $\mathbf{0 . 0 2}$ \\
prey/plant & & & \\
\% of leaves with prey & 0.14 & 0.22 & $\mathbf{0 . 0 2}$ \\
S. papillosum & & & \\
$\delta^{15} \mathrm{~N}$ & $\mathbf{0 . 0 4}$ & 0.39 & $\mathbf{0 . 0 0 1}$ \\
C:N & $\mathbf{0 . 0 0 4}$ & 0.68 & $\mathbf{0 . 0 0 7}$ \\
$\% \mathrm{~N}$ & $\mathbf{0 . 0 0 7}$ & 0.76 & 0.35 \\
\hline
\end{tabular}

539

540

541

542 


\section{Legends of Figures}

544 Figure 1

545 Impact of wet $\mathrm{N}$ deposition on $\delta^{15} \mathrm{~N}, \% \mathrm{~N}$ and $\mathrm{C}: \mathrm{N}$ ratio of $D$. rotundifolia plants and $S$.

546 papillosum capitula growing in Sphagnum turfs transplanted into the Whim Moss $\mathrm{N}$

547 deposition experiment. Presented are the mean \pm SEM for plants growing at four

548 levels of $\mathrm{N}$ deposition in two years. Levels of $\mathrm{N}$ deposition represent total rates of

549 deposition, taking into account background inputs of approximately $8 \mathrm{~kg} \mathrm{~N}^{-1}$ year $^{-}$

$550{ }^{1}$, numbers in parenthesis are the rates of additional $\mathrm{N}$ applied to plots. Mean values

551 represent reduced and oxidized $\mathrm{N}$ deposition. Letters indicate significance of

552 difference between each $\mathrm{N}$ deposition rate, regardless of year (there was no

553 significant year $\times \mathrm{N}$ deposition interaction for any of the measures) (Fisher's LSD,

$554 P<0.05)$. The significance of the main effect of year is presented for each measure.

\section{Figure 2}

556 Impact of reduced $\left(\right.$ as $\mathrm{NH}_{4} \mathrm{Cl}$ ) or oxidised (as $\left.\mathrm{NaNO}_{3}\right) \mathrm{N}$ deposition on $\delta^{15} \mathrm{~N}$ of $D$.

557 rotundifolia plants growing in Sphagnum turfs transplanted into Whim Moss $\mathrm{N}$

558 deposition experiment. Presented are mean \pm SEM for control (i.e. no additional $\mathrm{N}$

559 added) or the combined mean for each of the two forms of added N. Symbols with

560 different letters are significantly different from each other (Fisher's LSD, $P<0.05$ ).

561 Figure 3

$562 \delta^{15} \mathrm{~N}$ of $S$. papillosum, D. rotundifolia and a sample of potential $D$. rotundifolia insect

563 prey for $S$. papillosum turfs transplanted into the Whim Moss $N$ deposition

564 experiment. Presented are the mean \pm SEM for $S$. papillosum and insect $\delta^{15} \mathrm{~N}$ in 2008

565 (open symbols) and 2009 (closed symbols). The values for $D$. rotundifolia are

566 presented as the mean for all plants in 2008 and 2009 and the mean for the

567 individual plant with the lowest $\delta^{15} \mathrm{~N}$ in each treatment in 2008. Letters indicate

568 significant differences between bars (Fisher's LSD, $P<0.05$ ). 
Fig. 1

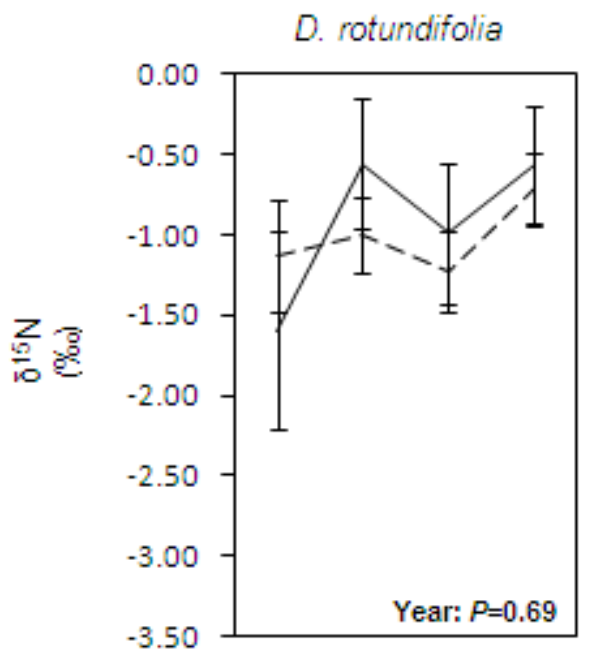

S. papillosum
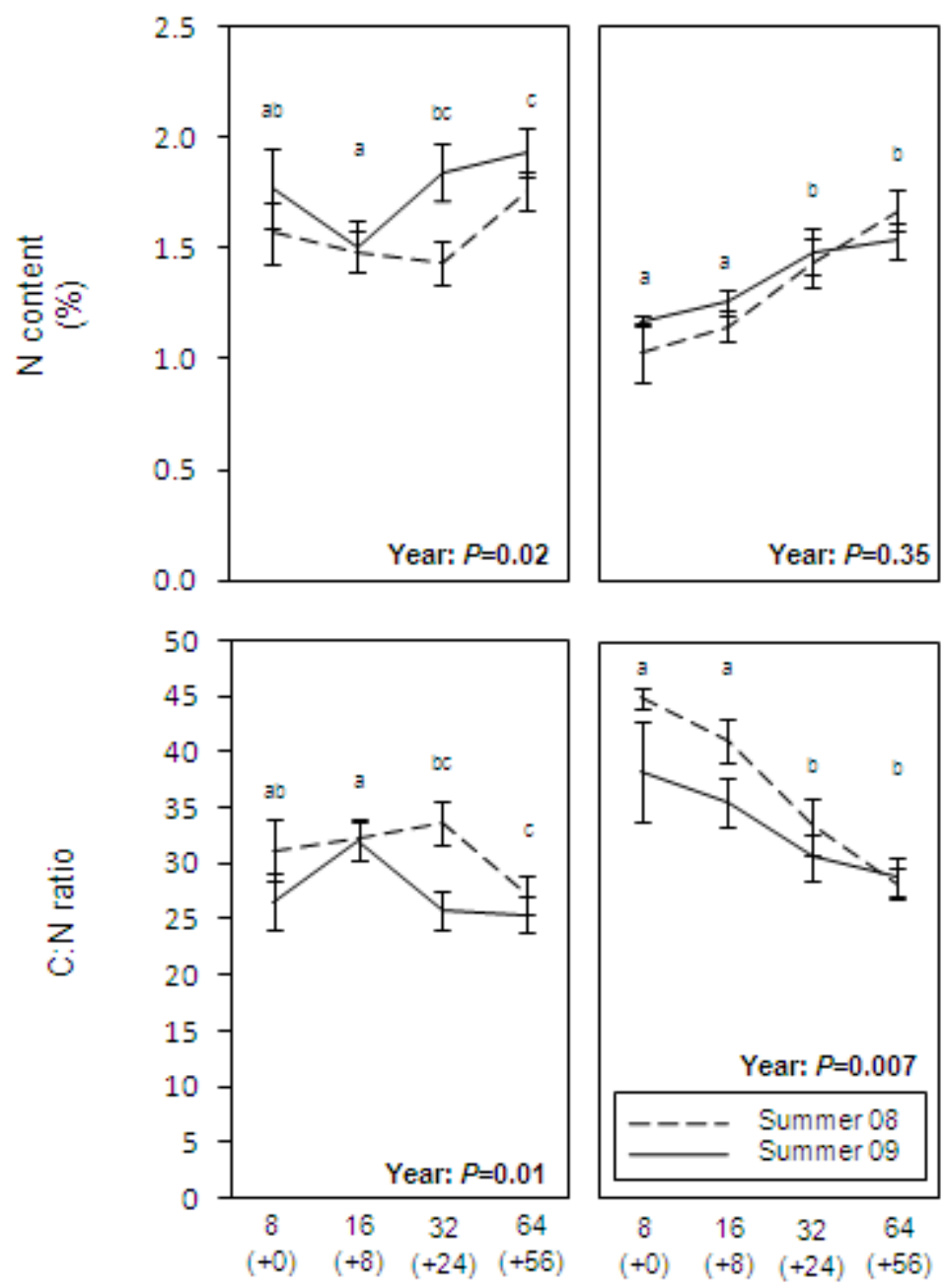

571

Wet $\mathrm{N}$ deposition $\left(\mathrm{kg} \mathrm{N} \mathrm{ha}^{-1} \mathrm{yr}^{-1}\right)$ 
573 Fig. 2

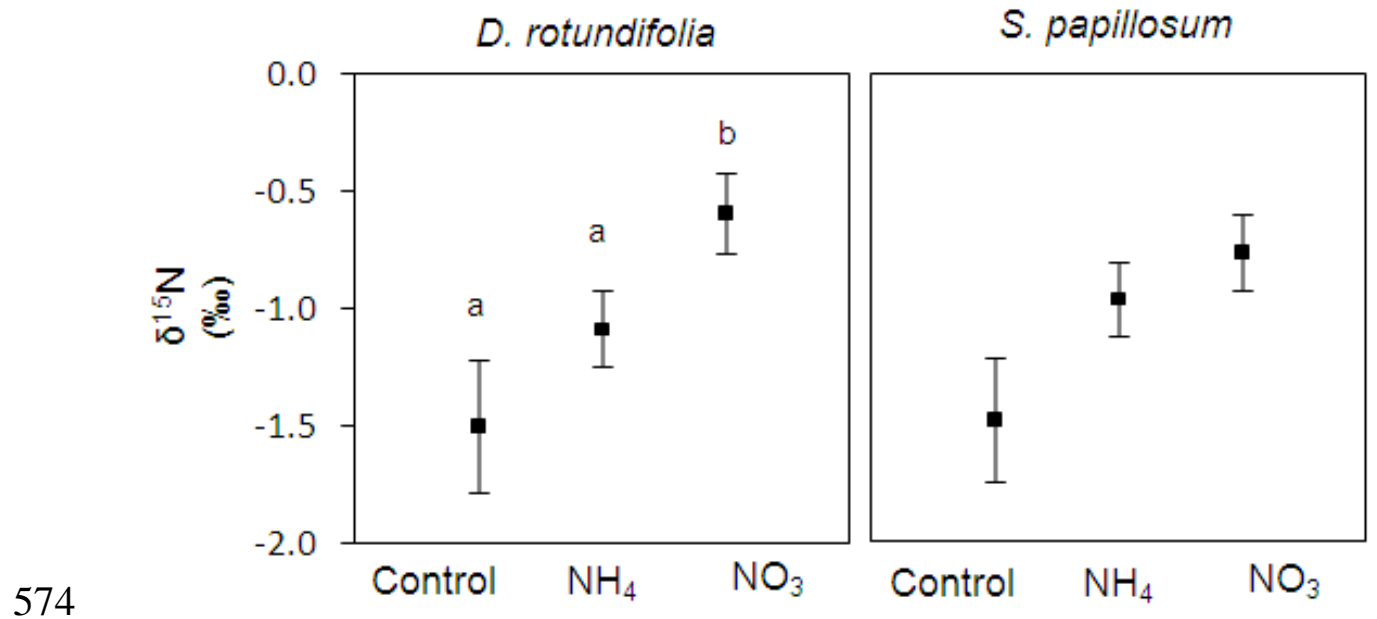

575

576 Fig. 3

577

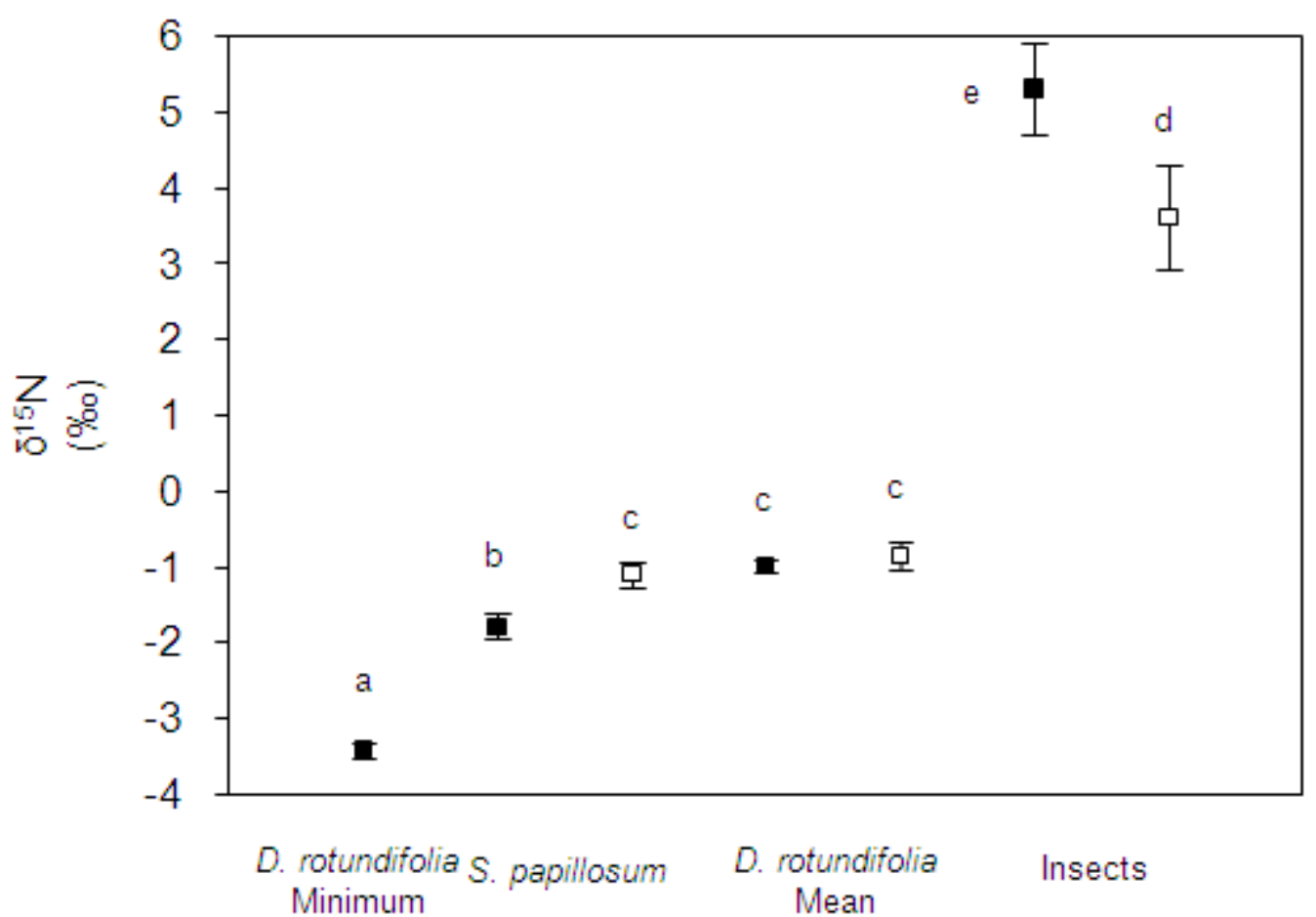

578 